\title{
The causes of the English teachers' problems on professional competence at Vocational High School
}

\author{
Syamsinar $^{* 1}$, Khaeruddin ${ }^{2}$ \\ ${ }^{1}$ STIE Tri Dharma Nusantara Makassar, Economic Faculty, Management Department, \\ Makassar, 90111, Indonesia \\ *e-mail: hinarshine@gmail.com \\ ${ }^{2}$ University of Newcastle Australia, Faculty of Education and Arts, School of \\ Education, Newcastle-New South Wales, 2287, Australia \\ e-mail: khaeruddin@uon.edu.au
}

\begin{abstract}
The objectives of this research aimed at finding out the causes of the problems in teaching English and the possible solution toward the problems of the teachers in teaching English subject at vocational high schools. The researcher applied the purposive sampling technique in selecting the participants. The participants consisted of two advanced teachers and two beginner teachers at vocational high schools in Somba Opu sub-district. The additional participants were two headmasters that focused on the possible solution for dealing with the problem found by the English teachers at VHS. This research used a descriptive approach and qualitative method. The data collected using two instruments namely semi-structured interview and observation checklist. The data analyzed by using the framework of Miles and Huberman. The results of this research revealed nine causes of the problems on the professional competence of English teachers in teaching at vocational high school and the possible solution toward the causes. The outline of the causes of the problems on professional competence are the less effort of the English teachers to improve the linguistic aspects, lack of English for Specific Purpose knowledge, less of communicative competence, less preparation of teaching contents, less in using ICT as a teaching method and lack in managing the time and managing the class. The possible solution found in this research that the English teachers at VHS have to consider the students' need, prepare the teaching planning and involved in the teaching training. Thus, this research recommends the government and the Educational trainer to facilitate the English teachers at VHS with education training of ESP knowledge and supporting the teachers in developing their professional competence.
\end{abstract}

\section{Keywords:}

Teacher competence; professional competence; Vocational High School

\section{INTRODUCTION}

The vocational high school has a vision and mission that is to achieve the international standard of Vocational High School (VHS). In this global era, facing Asian Economic Community, the students of VHS not only demanded to improve and master their skills but also demanded to speak English well in order that they can compete with the foreign labor either in Indonesia or other countries. This is due to the English language is considered the third rank of 
the most spoken language in the world (Lewis, 2009). Furthermore, School has an important role to contrive the students to be knowledgeable and skillful, and the teacher is a facilitator to help the students to acquire their skills. Those skills are ways of thinking creatively and critically, able to solve the problem, making decision and learning, using ICT, and skills; citizenship, life and career, personal and social responsibility (Schleicher, 2012). In this case, the teachers not only required to fulfill the academic qualification but also they must have competences in order to innovate and continuously adapt such as being critical, to innovate, model (attitude), enable in responding the outcomes of the students, and having professional dialogue to adopt the practices (European Commission, 2013).

Furthermore, competence is the combination of knowledge, skills, comprehension, behavior, and ambition of a person in a particular discipline (Deakin-Crick, 2008). While in Oxford Advanced Learner's dictionary, competence is being able to do something well. So, the competence is knowledge, skills, and behavior that enable someone to do something well. While competency is the ability to perform the teaching and learning process successfully (Lauermann \& König, 2016). Also, the European Commission, (2013) defined the teacher competence as the organization of teacher professionalism for multiple levels such as the individual, the school, the community and also professional networks.

The Russian researchers bring into the mutual interrelationship between the competences concepts with professionalism. It means that the competence cannot be separated with the professionalism. (Mustafa, 2013) Concluded that the professional competency of teachers is vital because the teachers who have high professional competency capable of leading the students in getting both excellent academic result and lead them to be the holistic students in an appropriate way. The professional skills and competencies that Southeast Asian teachers must have namely participated in professional community, providing leadership characters, finish the tasks punctually, obey the policies and rules, exhibiting the professionalism by having interaction with peers and others and maintain the cooperation with the students' parents and the society (SEAMEO INNOTECH Research Updates, 2014).

In addition, Dikilitaş and Yaylı (2018) stated that the professional competence of the teachers should possess-able to master the subject taught, able to make lesson plan, able to manage the class, able to use media or ICT, able to understand the characteristic of the pupils, able to select or to adopt the materials, and able to carry out the research. The professional competence covers the depth knowledge of teachers toward their field of study, enhance the learning process by using media, and their capability to develop their skills. So, as an ideal teacher must have a proper qualification, and master the professional competence. The quality of teaching competence is significant in creating and establishing the learning process. Also, it is suggested that the teacher must improve his quality in delivering material to meet the professional standards. These professional standards cover the working style, the practice of teaching and the use interactive approach in communicating the material (Walker, Jeffes, Hart, Lord, \& Kinder, 2011). 
Nevertheless, Biggs (2011) stated that most teachers are a lack of professionalism. The problems are many teachers do not adequately perform their duties professionally, having a low level of loyalty dealing with teaching norms and ethics, and dissatisfaction of acknowledgment concerning to institutional knowledge. Mustafa (2013) revealed that teachers have less competent especially in classroom management and in using media as educational resources. Also, many teachers found a problem in teaching ESP courses and designing the material might due to the lack of training, the material content and in providing supplementary materials, and lack of resources. The selection and decision is an urgent problem which is always faced by the teachers in the learning process especially in English teaching for vocational high schools.

In line with the problems above, Syamsinar and Jabu (2016) found eleven problems dealing with professional competence of English teacher in teaching at vocational high schools. The problems found are: 1) unfamiliar with vocabulary of unique terms for various fields of study, 2) lacking pronunciation of certain words, 3) difficult in communicating the lesson, 4) Difficult to reach the necessary competence and target of learning objectives, 5) Lacking planning the lesson, 6) Difficult to select the materials in accordance with the level of the students for different fields of study, 7) Difficult to design the relevant material for the students in different fields, 8) Difficult to obtain material from other sources, 9) Lacking of teacher activities for developing the professionalism, 10) Do not use information and communication for communicating maximally, and 11) Lacking classroom management

\section{METHOD}

This research employed a descriptive approach and qualitative method to investigate the causes of the problems found by the English teachers at VHS. In this research, the researcher took the vocational high schools in Somba Opu sub-district as the participants they are State Vocational High School 2 Somba Opu and State Vocational High School 3 Somba Opu. The researcher had two criteria in taking the participants, namely the advanced beginner teachers and the expert teachers. Furthermore, two expert teachers and two beginner teachers were taken from each school. The additional participants were the headmasters from the two vocational high schools. The data from the headmasters focused on the suggestion to the problems faced by teachers. The instruments used were a semi-structured interview to investigate the causes of the problems and checklist observation to verify the data collected. The data analysis steps based on Huberman, Miles, and Saldana (2013) that consists of data reduction, data display, and conclusion.

\section{FINDINGS}

\subsection{English Teachers' Problems in Professional Competence}

The following data was gained from the interview and observation from the participants of the English teacher at the vocational high school; they are 
teacher 1 , teacher 2, and teacher 3. The explanation is the summarized in terms of the causes of the English teachers' problems in professional competence at vocational high schools.

\subsubsection{Less effort to learn the vocabulary of vocational terms for various departments}

Teacher 1 stated that her problem was because she teaches various departments in which automatically she has to correlate with the department. There were two causes of this problem. First, she had less necessary of ESP. Second, the vocabularies in the module were general.

(Mastering the basic of ESP is a little bit less, and the vocabulary in a module provided most of them be NIL the general only). (Interview with teacher 1)

Different from teacher 1, teacher 2 and teacher 3 stated that the cause of not mastering the technical terms coming from the students' side. The causes are stated below.

(Because I was not familiar with the department of the students. My education background is in English. Perhaps, if this vocational school focuses on the Tourism, we can adapt easily. However, if it is more specific such as Engineer or Performing, we need personal learning). (Interview with teacher 2)

(Sometimes the students have a few vocabularies. So I have less motivation to learn more about vocabulary. Thus, usually, only the general vocabulary which I often hear I taught). (Interview with teacher 3)

Teacher 2 implied that the cause of difficult to master the vocabulary for the vocational term is because she was not very familiar with the students' department. She mastered the vocabulary which concerns the Tourism department. However, the difficult vocabulary for her was the vocabulary which concerns to the Engineer and Performing department. Whereas, teacher 3 stated that the cause was coming from the students' side. Teacher 1, teacher 2 and teacher 3 realized that they lacked the special terms, but they were not willing to identify the special terms of the students' department. It can be concluded that they were less effort to learn more the vocabulary for particular terms.

\subsubsection{Seldom to have pronunciation practice}

It was found that teacher 3 faced a problem dealing with pronunciation. The cause of her problem is revealed in the following statements.

(The cause is there are my friends to communicate by using English. If I meet with the teachers of English, I ask. However, we are seldom to meet each other. Moreover, sometimes if we meet, we talk about another thing). (Interview with teacher 3)

She stated that she seldom practice her English with the English teachers around her in the school because they seldom to meet each other in the school. Thus, the researcher considered that teacher 3 seldom practiced her English skills. 


\subsubsection{Less of communicative competence}

There were two teachers faced problem in strategic competence. They were teacher 1 and teacher 2. Teacher 1 wanted to use English in communicating with the students, but they had a low capacity in English. The cause of her problem is:

(When I want to interact with students by using English, it is like starting from the beginning because of the students' capacity is very low. So communicating by using English maximally has not been achieved yet). (Interview with teacher 1)

(Actually, sometimes there are vocabularies which I do not know the English) (Interview with teacher 3)

The cause of the problem of communicative competence is the students have low capacity for communicating in English, and the teacher cannot balance the students' capacity. Whereas, teacher 3 faced the problem in communicating the lesson with her students by using English in which the problem is coming from both students' and teacher side. Based on the simple statement above, the cause of the strategic competence is still about the teachers' problem in mastering the English vocabulary, so the students also had a low vocabulary in understanding the English material.

\subsubsection{Lacking time management to reach the necessary competence and learning objectives}

Teacher 1 explained that the cause of her problem dealing with the standard competence is to the time allocation in the teaching process.

(Actually, to reach the learning target which has been determined, I am restricted with the time in order the expected basic competence reached whereas the students' knowledge is still in basic level and for them is a little awkward). (Interview with teacher 1)

She thought that the limited time becomes the restricted for her to reach the necessary competence. Moreover, also the students needed more explanation due to their basic knowledge of English was very low achievers. By this information, teacher one is lacking time management in teaching the low achievers.

\subsubsection{Less effort to make a lesson plan}

Based on the observation, teacher 1 never brought a lesson plan. Thus the researcher needed information dealing with the cause of the problem.

(Sometimes, I borrow the lesson plan from the senior teacher. (Interview with teacher 1)

Teacher 1 did not make a lesson plan for this semester because she borrowed the lesson plan from an expert teacher. It means that she neither copied nor had personally archive toward the lesson plan. 


\subsubsection{The content of the book is English for General purposes, and the}

teachers lack references

In developing the material, the participants found a problem in selecting the materials and adapting the relevant materials for students. Teacher 1 stated before that the problem is in applying the material which is not specific for students. This problem is caused by the book content as stated below:

(Because the books which are provided by the school are too general, it has not focused on their department. Thus, I have to find out the material from other sources. However, it is not supported by the facility from school to update the relevant material for students). (Interview with teacher 1)

According to her, there were two causes of this problem. First, the materials from the available books are too general for students of various departments. Second, the school does not support regarding the facility. During the observation, she only used one module.

In another case, teacher 2 stated different causes in developing the material. The cause in selecting and adopting the material is described as follow.

(The book of vocational high schools is generally written for all departments. Meanwhile, each department has different needs. They will have different needs with them who are from Technology, Cooking background, Design and something like that, moreover, the books in the school are limited). (Interview with teacher 2)

The books are generally written for various departments. Teacher 2 wanted to change and adapt the material, but she did not do have any choice, she did not have any references. She only used the books which are provided in the school.

\subsubsection{Lacking ESP knowledge to adapt the relevant material}

The lack of ESP makes her difficult to adapt and develop the material to be related to the students' needs. The data is described below.

(My ESP knowledge capacity is a little bit less, so if adapting the material is a little bit difficult because as well as possible teaching one department for example in adapting the material, I have to find the way to correlate with their department which is not only theoretical but can be applied outside). (Interview with teacher 1)

(I do not know about ESP... how is the example? However, what I got in educational training was the general). (Interview with teacher 3)

In line with teacher 1 , teacher 3 stated that she had an obstacle with the vocabulary for each department. Thus, she taught the same material for different departments. In another case, teacher 3 graduated from the NonEnglish department.

Nevertheless, she knows English and teaches English. The problem is she did not know about English for a specific purpose (ESP). Also even in educational training of teacher that she attended, she had not got a little information about the ESP material in teaching for vocational school. According to the statement above, the cause of the problem in adapting the 
material of teacher 3 is she was not familiar with the vocabulary for each department, and she did not know the ESP knowledge.

3.1.8 Depending on the school facility to update the sources of material

In updating the material from many sources, there were three teachers found that they faced a problem, they were teacher 1 , teacher 2 and teacher 3 .

(There is no internet access). (Interview on April 7h 2014)

(The first is as I had explained. First, is a network problem, we do not have a network, and we cannot build the network because of the unavailable of internet access. Second, maybe if the vocational school is more prioritize the departments, training and something like that while the general teachers are not too prioritized). (Interview with teacher 2)

(Yes... there is no internet network.

Moreover, I seldom meet with English teachers here. (Interview with teacher 3)

Teacher 1, teacher 2, and teacher 3 shared the same cause that the internet access is the cause of their problem to be updated in learning from many sources.

\subsubsection{Lacking information for teacher developing activities}

Teacher community is considered the place to learn, share or discuss information to update the teacher professional competence. There were three teachers found they were teacher1, teacher 2 and teacher 3 who did not attend the English teacher community in their region when deals with teaching activities. The first data presented as follows.

(No activities which are provided by the school to develop the teachers' professionalism). (Interview with teacher 1)

(Maybe I do not update. Do not specialize for senior high school teachers only but also for a vocational teacher in order we can share the material).

(Interview with teacher 2)

(I am not sure if there is, but I do not know. We are less of communication (Interview with teacher 3)

Teacher 1 thought that the cause of her problem to be lack of developing activities was because the school did not provide the activities for supporting the teachers to be professional. Whereas teacher 2 and teacher 3 never heard before about the English teachers community. Also, teacher 3 also stated that she has less communication with the English teachers in her school. Even though they met, they did not discuss the lesson.

3.1.10 Lazy to use information and communication technology for communicating the material

The cause of the problem in using information and communication technology for communicating especially in communicating with the students for learning is stated below.

(Yeah, facility). (Interview with teacher 2) 
(It is still inadequate for the facility. The problem is because there is not a language laboratory. So, if we want to explain by using $L C D$, we have to carry the LCD back and forth from one room to other rooms. So sometimes if I am diligent, yes I will do, but if I am grudging, I will not use it, because it is complicated I there is not language laboratory). (Interview with teacher 3)

The incomplete of facilities is the cause of teacher two problems in using information technology for teaching. Also, teacher 3 stated sometimes she was diligent to carry the LCD to the classes but sometimes she was grudging. Whereas teacher 1 explained stated that the system in their school was "moving class". So, several teachers responsible for certain classroom, for instance in the language laboratory is functioned for studying class by other English teachers. Even the teachers use the lab as the class but they did not give a listening. They mostly teach by using a whiteboard.

\subsubsection{Difficult to control the students}

Based on the interview data which was gained from the students of teacher 1, they stated that teacher 1 faced difficulty in managing the students in the class. Then the researcher clarified this problem to teacher 1 . She confirmed the caused that the students were difficult to control. The interview data is presented below.

(Because the students were difficult to manage). (Interview with teacher 1)

\subsection{The possible solution toward the problems of the teachers in teaching English subject}

The possible solution came from the Headmaster of each school and the English teachers (teacher 1, teacher2, teacher 3, and teacher 4). Due to teacher 4 was the expert teacher who did found any problems with the professional competence thus, he actively shared the suggestion for other English teachers. Headmaster 1 came from English education major field whereas Headmaster 2 was from Engineer department. The possible solution is summarized by presenting in a table.

Table1. The suggestions on possible solution toward the problems of professional competence

\section{The possible Solution \\ Data of Participants}

\begin{tabular}{ll}
\hline A. Mastering the material, the & Teacher $\mathbf{4}$ \\
structure and the concept of the & $\begin{array}{l}\text { a. Share with another teacher } \\
\text { subject taught }\end{array}$ \\
$\begin{array}{ll}\text { b. Provide the educational } \\
\text { training of vocational term }\end{array}$ \\
$\begin{array}{ll}\text { all the vocabularies of unique } \\
\text { terms for various departments }\end{array}$ & $\begin{array}{l}\text { c. Formulate the technical terms } \\
\text { of the department into the } \\
\text { students reading }\end{array}$ \\
\end{tabular}

DOI: 10.33750/ijhi.v1i2.9

ISSN: 26146169

@Center for Humanities and Innovation Studies 
d. Consider who are taught, what department, and what technical terms they study

\section{Headmaster 1}

a. Find more books

b. Provide the visual aids and introduce in English

2) How to improve pronunciation

a. Listen to the English music, video, news and practice with the English native speaker.

b. Use English learning software and dictionary

c. Listen to the English comprehension cassette frequently

\section{Teacher 1}

Listen to the English music, film, and practice with a native speaker

\section{Teacher 2}

Listen to the English music, a film in video and English news

\section{Teacher 4}

Use English learning software and use the dictionary

\section{Headmaster 1 \\ Listen to the English comprehension cassette frequently}

3) Switch the language to communicate with the students by using English

\section{Teacher 2}

Do more practice

\section{Teacher 4}
a. Mix switching
b. Combine that strategy with factual things

\section{Headmaster 2}

Teach based on the educational discipline

B. Mastering standard competence and basic competence of the subject taught

1) How to reach the necessary competencies and learning objectives
a. Combine the necessary competencies with other necessary competencies and the learning objectives with other learning objectives
b. Learning outside

\section{Teacher 2}
a. Directly refers to the indicator
b. Combine the basic competence with other basic competence

\section{Teacher 3}
a. Check indicator
b. Decide the learning objective which can be combined

\section{Teacher 4}

Select the basic competence which can be combined and the learning objective 


\begin{tabular}{|c|c|}
\hline \multirow[t]{3}{*}{$\begin{array}{l}\text { c. Analyze the basic } \\
\text { competence }\end{array}$} & $\begin{array}{l}\text { Headmaster } \mathbf{1} \\
\text { Learning outside to achieve } \\
\text { necessary competencies and } \\
\text { learning objectives }\end{array}$ \\
\hline & Headmaster 2 \\
\hline & $\begin{array}{l}\text { Analyze the necessary } \\
\text { competence and measure the } \\
\text { teacher's capacity. }\end{array}$ \\
\hline $\begin{array}{l}\text { 2) The teachers should make a } \\
\text { lesson plan }\end{array}$ & $\begin{array}{l}\text { Teacher } \mathbf{2} \text {, teacher } \mathbf{2} \text {, teacher } \\
\mathbf{3} \text {, teacher } \mathbf{4} \text {, headmaster } \mathbf{1}, \\
\text { and headmaster } \mathbf{2} \text {. } \\
\text { The teacher should make a } \\
\text { lesson plan by the expert teacher } \\
\text { guidance. }\end{array}$ \\
\hline \multirow{8}{*}{$\begin{array}{l}\text { C. Developing the learning material } \\
\text { creatively } \\
\text { 1) How to select the appropriate }\end{array}$} & The Possible Solution \\
\hline & Teacher 2 \\
\hline & $\begin{array}{l}\text { Suit the material with a lesson } \\
\text { plan and provide many } \\
\text { references }\end{array}$ \\
\hline & $\begin{array}{l}\text { Teacher } 4 \\
\text { a. Take the relevant material } \\
\text { from many references } \\
\text { b. Find the related discourse }\end{array}$ \\
\hline & $\begin{array}{l}\text { Headmaster } 1 \\
\text { a. Compose the relevant stories } \\
\text { for the students' department } \\
\text { b. Find related stories from } \\
\text { many references. }\end{array}$ \\
\hline & Headmaster 2 \\
\hline & $\begin{array}{l}\text { a. Analyze the syllabus and then } \\
\text { find the handbook }\end{array}$ \\
\hline & $\begin{array}{l}\text { b. Curriculum } 2013 \text { provides a } \\
\text { handbook for students and } \\
\text { teachers }\end{array}$ \\
\hline \multirow{6}{*}{$\begin{array}{l}\text { 2) How to adapt the material to be } \\
\text { relevant for the students } \\
\text { a. Involve the ESP by } \\
\text { considering the students' } \\
\text { interest and students' needs } \\
\text { b. Relevant the material with } \\
\text { the students' needs } \\
\text { c. Orientate the material with } \\
\text { the students' department } \\
\text { activities }\end{array}$} & $\begin{array}{l}\text { Teacher } 4 \\
\text { a. Combine the ESP knowledge } \\
\text { with material } \\
\text { b.Share with the teachers }\end{array}$ \\
\hline & Headmaster 1 \\
\hline & $\begin{array}{l}\text { Visit the workshop then relevant } \\
\text { the material. }\end{array}$ \\
\hline & Headmaster 2 \\
\hline & $\begin{array}{l}\text { Orientate the material with the } \\
\text { students' department activities }\end{array}$ \\
\hline & Teacher 2 \\
\hline
\end{tabular}


d. The government is expected The government must facilitate to deliberate the teachers to the teacher to do the module do the module

D. Developing the teacher professionalism continuously

1) How to update the material from many sources

a. Facilitate personally

b. Provide the internet access

The possible solution

Headmaster 1

a. For the certified teacher should facilitate herself

b. The school should provide internet access

\section{Headmaster 2}

The school is in the process to provide the internet access

2) Participating in developing Teacher 4 activities

Participate in action research competition

\section{Headmaster 1}

The teacher must be active, creative and innovative

\section{Headmaster 2}

Being activate in English teacher community and make teaching project

E. Using informational technology

\section{The possible solution}

\section{Teacher 1}

An audio-visual room to use for

The school should provide communicating maximally

internet access

\section{Headmaster 1}

The school should provide the language laboratory or particular room

\section{Headmaster 2}

The school will provide audiovisual room

\section{F. Classroom management}

The ways of managing the classroom

1) The teacher should be mobile and make a contract.

2) The teacher should master the material and use the exciting method

\section{Teacher 2}

a. The teacher should be mobile.

b. The teacher needs the agreement toward the learning contract 
The teacher should be mobile in

the classroom

\section{Teacher 4}

a. The teacher should make the learning contract with the students

b. The teacher should give the exciting learning method)

\section{Headmaster 1}

Agree with the students to silent the mobile phone

\section{Headmaster 2}

The teacher needs to master the material, use the method, learning sources and other things which support the learning and teaching process)

\section{DISCUSSION}

The EFL teacher of vocational high school even realized that they were not familiar with the vocational terms, but they had less effort to identify and list the terms more (Nur, Patak, \& Naim, 2013). As the good English teachers, they should prepare their learners to deal with the large numbers of technical words (Nation \& Macalister, 2009). Another case was one of the English teachers was lacking pronunciation because she was seldom to practice her English, especially regarding pronunciation with the English teachers around her. The beginner teacher is challenging to decide the appropriate strategies to make all of the students engage in the teaching and learning activities. Also, she also lacks time management to cover the target of learning objectives in one meeting (Kayode \& Ayodele, 2015). The beginner teacher is less effort to make a lesson plan. Either the beginner or advanced teacher found difficulties in selecting the appropriate material because they lacked references.

Still, about the material, they lack ESP knowledge to adapt the material because they did not quite master the ESP content (Al-zahrani, 2014). The teachers did not become familiar with the gap between the knowledge of the learners' towards the special subject, and they were afraid if they might not be able to cope with students' area of specialism. Both expert and advanced beginner teachers hampered by the unavailable of the school facility to access the internet. Even the expert teacher who has certified did not have a modem to access. This is indicated that the teachers depend on the school facility to update the sources of material. Three of the English teachers at vocational high schools in Somba Opu district never attended in Teacher Working Group of Subject Matter or Teacher Working group. They also confirmed that they were troublesome to bring LCD to every class. The last, one of the beginner teacher found that she lacked classroom management because she faces difficulties in 
controlling the students (Mustafa, 2013). However, as the teacher, we have to put in mind that the students have different characteristics in the class.

Table.2. Summary of Discussion

\begin{tabular}{|c|c|}
\hline $\begin{array}{l}\text { The causes of the problems } \\
\text { in dealing with professional } \\
\text { competence in teaching } \\
\text { English at a vocational high } \\
\text { school }\end{array}$ & $\begin{array}{l}\text { The possible solution from English } \\
\text { teachers and headmasters toward the } \\
\text { problems dealing with professional } \\
\text { competence in teaching at the } \\
\text { vocational high school }\end{array}$ \\
\hline $\begin{array}{l}\text { Less effort to learn } \\
\text { vocabulary for various } \\
\text { departments }\end{array}$ & $\begin{array}{l}\text { - The teachers should consider who are } \\
\text { taught and what field of study are they } \\
\text { from } \\
\text { - visit the workshop and identify the } \\
\text { vocabulary which commonly they use } \\
\text { - Formulate the technical terms or } \\
\text { particular term into the students } \\
\text { reading } \\
\text { - The government must provide the } \\
\text { educational training of vocational } \\
\text { term. }\end{array}$ \\
\hline
\end{tabular}

Seldom to have pronunciation practice

- Listen the English music, video, news

- Play English listening comprehension cassette

- Learn from the English learning software and dictionary.

- Practice with the English native speaker strategy

- Less of communicative
- The teachers lacked competence

- The teachers can paraphrase the problematic words

- Switch the language into English or Indonesian

- Use verbal or non-verbal language and have more practice in teaching.

- Teach based on the discipline

Lacking time management to reach the necessary competencies and learning objectives

- Analyze the necessary competencies and learning objective would be achieved by the students

- Combine the learning objectives with another learning objectives of possible or at least combine the material with 
the material from another learning objective.

- Do project activities such as learning outside or conducted English meeting club in the school

less effort to make lesson

- The teacher should discuss her difficulties with the senior teachers at the school in writing lesson plan.

- The teacher may search the lesson plan from many sources then adopt.

- The content of book is English for General purpose

- The teachers are lacking of references
- Analyze the syllabus and then find handbook.

- Take the relevant material from many references
Some of the teachers are lacking of ESP knowledge to adapt the materials
- Involve the ESP by considering the students' interest and students' needs

- Relevant the material or orientate the with the students' needs

- The government is expected to deliberate the English teachers to make module.
The teachers depend on the school facility
- For the certified teacher must use the fund of certification to facilitate the teaching need.

- The headmaster would like to build up the internet access as soon as possible.
- Some of the teachers are Lacking of information for developing activities

- Less communication with other teacher
- The teacher must be active, creative and innovative

- - Being activate in English teacher community or Teacher Working Group of Subject Matter and make teaching project

- Participating in action research competition
- Lazy to use the informational technology
- The headmasters will facilitate internet access 
and communication for communicating

maximally
- The headmasters will provide them as a special room which can be used as audio-visual room to substitute the language laboratory
- Difficult to control the students
- The teacher should be mobile and make contract.

- Teacher should master the material and use interesting method

\section{CONCLUSION}

There were eleven causes of the problems faced by the English teachers of VHS at Somba Opu district. In a linguistic aspect, the teachers had less effort to improve their vocabulary and pronunciation. Nevertheless, among the group of expert teacher, there is a case found that an expert teacher of English who comes from other discipline is not the same with the real expert teacher of English in terms the professional competence. This is due to the low of linguistics aspect.

In developing material, they were lacking references and lacking ESP knowledge. Both expert and beginner teachers did not participate in the English teacher community because they did not have any information and less communication either with the team teaching or other English teachers from other schools. In conclusion, most of the causes of the problems come from the EFL teachers' side in dealing with their professional competence. They too depended on the school facility and less effort to improve their competence be professional teachers for the students of vocational high schools.

\section{REFERENCES}

Al-zahrani, M. Y. (2014). The Involvement of the General English Teachers into ESP Practice: Possibilities and Problems in ELI. International Journal of Science Comme Rce and Humanities, No 2 No 4(2), 55-73.

Biggs, J. B. (2011). Teaching for quality learning at university: What the student does. McGraw-Hill Education (UK).

Deakin-Crick, R. (2008). Pedagogy for citizenship. Getting Involved: Global Citizenship Development and Sources of Moral Values, 31-55.

Dikilitaş, K., \& Yaylı, D. (2018). Teachers' professional identity development through action research. ELT Journal.

European Commission. (2013). Supporting teacher competence development for better learning outcomes. The European Commission.

Huberman, A. M., Miles, M., \& Saldana, J. (2013). Qualitative data analysis: A methods sourcebook. Thousand Oaks, CA: Sage Publications Inc.

Kayode, G. M., \& Ayodele, J. B. (2015). Impacts of teachers' time management on secondary school students' academic performance in Ekiti State, Nigeria. International Journal of Secondary Education, 3(1), 1-7.

Lauermann, F., \& König, J. (2016). Teachers' professional competence and wellbeing: 
Understanding the links between general pedagogical knowledge, self-efficacy and burnout. Learning and Instruction, 45, 9-19.

Lewis, M. P. (2009). Ethnologue: Languages of the World. SIL International. Retrieved from https://books.google.co.id/books?id=FVVFPgAACAAJ

Mustafa, M. N. (2013). Professional Competency Differences among High School Teachers in Indonesia. International Education Studies, 6(9). https://doi.org/10.5539/ies.v6n9p83

Nation, I. S. P., \& Macalister, J. (2009). Language curriculum design. Routledge.

Nur, S., Patak, A. A., \& Naim, H. A. (2013). Using English instructional package model through Problem Based Learning approach in Vocational High School.

Schleicher, A. (2012). Preparing Teachers and Developing School Leaders for the 21st Century: Lessons from around the World. ERIC.

SEAMEO INNOTECH Research Updates. (2014). Teaching Competency Standards in Southeast Asian Countries: Eleven Country Audit. Retrieved from http://www.seameo-innotech.org/wp-content/uploads/2014/01/SIREP1

Teaching Standard FINAL.pdf

Syamsinar, S., \& Jabu, B. (2016). The Problems in Professional Competence of Teachers in Teaching English Subject at Vocational High Schools. ELT WORLDWIDE, 2(2), 95-109.

Walker, M., Jeffes, J., Hart, R., Lord, P., \& Kinder, K. (2011). Making the links between teachers' professional standards, induction, performance management and continuing professional development RR075. Department for Education. 